DR ATHANASIOS KALLIANIDIS (Orcid ID : 0000-0001-6078-1185)

DR ALICE MARASCHINI (Orcid ID : 0000-0003-4754-5385)

DR PELLE G LINDQVIST (Orcid ID : 0000-0002-1652-8235)

DR THOMAS VAN DEN AKKER (Orcid ID : 0000-0002-9890-9145)

Article type : Original Research Article

\title{
Epidemiological analysis of peripartum hysterectomy across 9 European
}

\section{countries}

Athanasios F KALLIANIDIS ${ }^{1}$, Alice MARASCHINI ${ }^{2}$, Jakub DANIS ${ }^{3}$, Lotte B COLMORN ${ }^{4}$, Catherine DENEUX-THARAUX ${ }^{5}$, Serena DONATI ${ }^{2}$, Mika GISSLER ${ }^{6,7}$, Maija JAKOBSSON

${ }^{8}$, Marian KNIGHT ${ }^{9}$, Alexandra KRISTUFKOVA ${ }^{3}$, Pelle G LINDQVIST ${ }^{10}$, Griet

VANDENBERGHE ${ }^{11}$, Thomas VAN DEN AKKER ${ }^{1,12}$ on behalf of INOSS (the International Network of Obstetric Survey Systems)

${ }^{1}$ Department of Obstetrics and Gynecology, Leiden University Medical Centre, Leiden, the Netherlands

${ }^{2}$ Instituto Superiore di Sanita, Rome, Italy

3 1st Department of Obstetrics and Gynecology, Faculty of Medicine, Comenius University, Bratislava, Slovakia

${ }^{4}$ Department of Obstetrics, Rigshospitalet University Hospital, Copenhagen, Denmark

This article has been accepted for publication and undergone full peer review but has not been through the copyediting, typesetting, pagination and proofreading process, which may lead to differences between this version and the Version of Record. Please cite this article as doi: 10.1111/AOGS.13892

This article is protected by copyright. All rights reserved 
${ }^{5}$ Inserm U1153, Paris University, Obstetric, Perinatal and Pediatric Epidemiology Research Team, Centre for Epidemiology and Statistics Sorbonne Paris Cite, Paris, France

${ }^{6}$ THL Finnish Institute for Health and Welfare, Information Services Department, Helsinki, Finland

${ }^{7}$ Karolinska Institute, Department of Neurobiology, Care Sciences and Society, Stockholm, Sweden

${ }^{8}$ Department of Obstetrics and Gynecology, Hyvinkää hospital HUCH, University of Helsinki, Helsinki, Finland

${ }^{9}$ National Perinatal Epidemiology Unit, University of Oxford, Oxford, UK

${ }^{10}$ Clinical Science and Education, Karolinska Institute, Department of Obstetrics and Gynecology, Sodersjukhuset Hospital, Stockholm, Sweden

${ }^{11}$ Department of Obstetrics and Gynecology, Ghent University Hospital, Ghent, Belgium

12 Athena Institute, VU University Amsterdam, The Netherlands.

ATHANASIOS F KALLIANIDIS (Orchid ID: 0000-0001-6078-1185)

ALICE MARASCHINI (Orchid ID: 0000-0003-4754-5385)

JAKUB DANIS

LOTTE COLMORN (Orchid ID: 0000-0001-7570-2822)

CATHERINE DENEUX-THARAUX (Orchid ID: 0000-0002-6561-3321)

SERENA DONATI (Orchid ID: 0000-0002-4607-2072

MIKA GISSLER (Orchid ID: 0000-0001-8254-7525)

MAIJA JAKOBSSON (Orchid ID: 0000-0003-0075-8375)

MARIAN KNIGHT (Orchid ID: 0000-0002-1984-4575)

ALEXANDRA KRISTUFKOVA

PELLE G LINDQVIST (Orchid ID: 0000-0002-1652-8235)

GRIET VANDENBERGHE (Orchid ID: 0000-0002-7420-5020)

THOMAS VAN DEN AKKER (Orchid ID: 0000-0002-9890-9145)

\section{Corresponding author:}

Athanasios Kallianidis

Leiden University Medical Centre, K6-35, PO Box 9600, Leiden 2300 RC, the Netherlands 
Email: a.f.kallianidis@lumc.nl

\section{Conflicts of interest}

None

ABSTRACT

Introduction: Peripartum hysterectomy is a surgical procedure performed for severe obstetric complications such as major obstetric hemorrhage. The prevalence of peripartum hysterectomy in high-resource settings is relatively low. Hence, international comparisons and studying indications and associations with mode of birth rely on the use of national obstetric survey data. Objectives were to calculate the prevalence and indications of peripartum hysterectomy and its association with national cesarean section rates and mode of birth in nine European countries. Material and methods: We performed a descriptive, multinational, population-based study among women who underwent peripartum hysterectomy. Data were collected from national or multi-regional databases from nine countries participating in the International Network of Obstetric Survey Systems. We included hysterectomies performed from 22 gestational weeks up to 48 hours postpartum due to obstetric hemorrhage, since this was the most restrictive, overlapping case 
definition between all countries. Main outcomes were prevalence and indications of peripartum hysterectomy. Additionally, we compared prevalence of peripartum hysterectomy between women giving birth vaginally and by cesarean section, and between women giving birth with and without previous cesarean section. Finally, we calculated correlation between prevalence of peripartum hysterectomy and national cesarean section rates, as well as national rates of women giving birth after a previous cesarean section. Results: 1,302 peripartum hysterectomies were performed in $2,498,013$ births leading to a prevalence of 5.2 per 10,000 births ranging from 2.6 in Denmark to 10.7 in Italy. Main indications were uterine atony (35.3\%) and abnormally invasive placenta (34.8\%). Relative risk of hysterectomy after cesarean section compared to vaginal birth was 9.1 (95\% confidence interval [CI] 8.0-10.4). Relative risk for hysterectomy for birth after previous cesarean section compared to birth without previous cesarean section was 10.6 (95\% CI 9.4-12.1). A strong correlation was observed between national cesarean section rate and prevalence of peripartum hysterectomy $(\rho=0.67, p<0.05)$. Conclusions: Prevalence of peripartum hysterectomy may vary considerably between high income countries. Uterine atony and abnormally invasive placenta are the commonest indications for hysterectomy. Birth by cesarean section and birth after previous cesarean section are associated with nine-fold increased risk of peripartum hysterectomy.

\section{Keywords}

maternal morbidity, mode of birth, obstetric hemorrhage, peripartum hysterectomy, cesarean section,

\section{Key Message:}

Peripartum hysterectomy rates vary considerably between high income countries and are associated with national cesarean section rates.

\section{Abbreviations}

INOSS International Network of Obstetric Survey Systems 


\section{INTRODUCTION}

Peripartum hysterectomy refers to surgical removal of the uterus during pregnancy or postpartum.(1) It is usually performed for severe obstetric complications such as major obstetric hemorrhage, abnormally invasive placenta, uterine rupture or sepsis. Peripartum hysterectomy is defined by the World Health Organization as a maternal near miss criterion and used as a proxy for severe postpartum hemorrhage and therefore frequently used as an outcome of interest in obstetric surveillance.(2) .

The association between peripartum hysterectomy and cesarean section has previously been described, with relative risk for women giving birth by cesarean section ranging from 8.5 to 18.3.(3-8) In addition, pregnancy in a woman who gave birth by cesarean section previously is a risk factor for abnormally invasive placentation, which may in turn lead to hysterectomy. This risk is known to increase for every additional previous cesarean section.(9) Such associations are of particular interest in light of the rising cesarean section rates world-wide as these could potentially lead to increasing rates of peripartum hysterectomies as well.

Prevalence of peripartum hysterectomy in high-resource settings is relatively low.(10) Hence, indications and outcomes are often studied retrospectively, or through national obstetric survey systems.(11-15) Multinational comparisons of prevalence and outcomes in order to optimize management strategies may be facilitated by international collaborations combining national data. $(1,16)$

Main aim of this study was to compare the prevalence of peripartum hysterectomy between high-income countries, as part of the International Network of Obstetric Survey Systems (INOSS). Secondary aims were to describe the indications for hysterectomy, and perform analyses of prevalence of peripartum hysterectomy stratified by mode of birth and previous cesarean section. In addition, we examined the correlation between national rates of peripartum hysterectomy and national cesarean section rates, and the rate of women giving birth after previous cesarean section.

\section{MATERIAL AND METHODS}

This was a descriptive, multinational, population-based study. We used data from nine countries participating in INOSS who had previously conducted studies on peripartum 
hysterectomy. Most of these countries, except France and Slovakia, have previously published outcomes of peripartum hysterectomy surveillance.(11-15, 17-20) INOSS is an international collaboration of national obstetric survey systems, aiming to increase knowledge of management of uncommon obstetric complications.(16) Participating in this study were: Slovak Obstetric Survey System (SOSS) in Slovakia, Italian Obstetric Surveillance System (ItOSS) in Italy, Belgian Obstetric Surveillance System (B.OSS) in Belgium, Epidemiologie de la Morbidite Maternelle Severe (EPIMOMS) in France, Nordic Obstetric Surveillance System (NOSS) with data from Denmark, Finland and Sweden, Landelijke studie naar Etnische determinanten van Maternale Morbiditeit (LEMMoN) in the Netherlands and United Kingdom Obstetric Surveillance System (UKOSS) in the UK. All were nationwide studies except for EPIMOMS in France which included six regions (Alsace, Auvergne, Basse-Normandie, Île-de-France, Lorraine and Rhône-Alpes) covering $20 \%$ of national births and ItOSS, which encompassed six regions (Piedmont, EmiliaRomagna, Tuscany, Lazio, Campania and Sicily) representing $49 \%$ of births in Italy.

Methods of data collection were described previously.(20-25) In brief, all countries performed national or multi-regional survey studies in which women who underwent peripartum hysterectomy were identified. Identification of cases was performed in most countries by monthly communication (electronic database, mailing or paper) to appointed clinicians in each maternity unit. When a case was reported, further details were requested through a data collection form. To ensure completeness of data, regular reminders were sent and a 'nothing to report' response requested. All data were collected prospectively, except for the data from Slovakia which were collected retrospectively. Studies were performed during different periods, from August 2004 to August 2016. Validation and identification of additional cases was performed after cross-checking health registers and hospital databases for the Nordic countries (Hospital Discharge Register, Medical Birth Register and delivery logbooks). Each country managed and cleaned their own database after which all anonymized databases were merged in Leiden, The Netherlands (Table S1).

In order to overcome differences in case selection between studies we applied a uniform case definition. Definitions used in the different survey studies were specified for inclusion criteria such as minimum gestational age, postpartum follow up, inclusion of non-obstetric indications (such as malignancy) or other specific in- or exclusion criteria if present (such as including only cases of obstetric hemorrhage in Italy) . In order to arrive at a uniform definition, the most restrictive definition was chosen to account for differences. We opted not to exclude 
hysterectomies in case of missing information regarding indication or gestational age, since it was postulated that the very few women who would have had an indication other than obstetric hemorrhage or a peripartum-hysterectomy before 22 weeks, would be greatly outnumbered by those with hemorrhage or hysterectomy $\geq 22$ weeks. The most restrictive definition was defined as hysterectomies performed from the $22^{\text {nd }}$ week of gestation up to 48 hours postpartum performed due to obstetric hemorrhage (Table S2).

All countries provided background data on number of births during the study period. Background data differed between countries on the lower limit of gestational age, ranging from $\geq 22$ weeks to $25+6$ weeks (Table S1). For countries registering births $\geq 24$ weeks or higher, calculation of births $\geq 22$ weeks was not possible. In a previous INOSS study, correction of background data resulted in minimal non-significant differences since the proportion of births at those gestational ages is very low in all countries. Therefore, we decided not to perform such correction.(26) Additionally, all countries provided aggregate data on national cesarean section rates, numbers of cesarean sections and vaginal births. When actual numbers of cesarean section and vaginal births were unknown, these were estimated by multiplying the total number of births by the cesarean section rate. Numbers of women giving birth with and without previous cesarean section were calculated accordingly.

There were differences between studies in coding indications of hysterectomy. Some countries reported only one indication per hysterectomy while others coded all indications that arose during the process leading to hysterectomy. Therefore, we included the most important indication of those registered by applying a hierarchical system. From the indications listed, the one highest in rank was used. The hierarchy of indications, which was determined after reaching consensus among researchers of participating countries, in order of importance, was as follows: abnormally invasive placenta, placenta previa, uterine rupture, placental abruption, uterine atony, infection, cervical laceration, fibroids, unspecified hemorrhage, diffuse intravascular coagulation and other.

Main outcomes were overall prevalence and indications of peripartum hysterectomy. Secondary outcomes were prevalence of peripartum hysterectomy for women giving birth vaginally and women who underwent cesarean section, and for women giving birth with and without previous cesarean section, with calculations of relative risk. Additionally, correlations between prevalence of peripartum hysterectomy and national cesarean section rates and national proportion of women giving birth after previous cesarean section. 


\section{Statistical analyses}

Prevalence was calculated per 10,000 births with 95\% confidence intervals (CI) or per 10,000 cesarean sections or vaginal births where appropriate. For calculation of relative risk, individual data were used from women with hysterectomy while only aggregate data were available for women without hysterectomy. In order to adjust for weighting and clustering, calculation of total proportions and relative risks was done using a fixed-effects model. Descriptive data are presented with mean $(95 \% \mathrm{CI})$ or median (interquartile range) whenever appropriate. Proportions were calculated after subtracting the missing from totals, since they cannot be classified in either category of binary variables. Correlation between prevalence of peripartum hysterectomy and mode of birth and previous cesarean section rates per country were calculated using nonparametric Spearman rank order correlations $(\rho)$. Results were considered statistically significant when $p<0.05$. All analyses were performed using IBM SPSS Statistics version 18.0 (IBM Corp.), R version 6.3 .6 (cran.r-project.org) and Office Excel 2019 (Microsoft Corp.).

\section{Ethical approval}

Due to the nature of this study ethics approval was not required. Each study, from which data were used, was approved by their national or local Ethics Committees.

\section{RESULTS}

A total of 1,393 peripartum hysterectomies were reported in the nine participating countries. During the study period, 2,498,013 births were registered. A total of 91 hysterectomies were excluded: 17 because the hysterectomy was performed at gestational age $<22$ weeks, 72 due to postpartum interval $>48$ hours, two hysterectomies because of indication other than obstetric hemorrhage (one gynecological malignancy and one necrotic uterus after uterine artery embolization). Using the uniform definition for all datasets 1,302 hysterectomies were included leading to a prevalence of $5.2(95 \%$ CI 4.9 - 5.5) per 10,000 births. Prevalence was highest in Italy with 10.7 (95\% CI 9.8 - 11.6) hysterectomies per 10,000 births and lowest in Denmark with 2.6 (CI 2.0 - 3.5) hysterectomies per 10,000 births (Table 1, Figure 1). Due to differences in the time period in which studies where performed, we compared countries that included cases before 2012 
(The Netherlands, Denmark, the UK, Finland, Sweden) to countries who included cases starting in 2012 (Italy, France, Belgium, Slovakia). The prevalence was $3.7(3.4-4.0)$ vs. $7.3(6.8-7.9)$ per 10,000 births respectively.

Overall, background characteristics such as maternal age, parity and body mass index were comparable between countries (Table 2). A total of 996/1292 (77.1\%) women gave birth by cesarean section and 452/770 (58.7\%) were planned. Moreover, 586/1177 (49.8\%) women had given birth by cesarean section in a previous pregnancy.

In 670 women multiple indications were coded before use of the hierarchical system. Commonest indication was uterine atony for 459 women (35.3\%) followed by abnormally invasive placenta for 453 women (34.8\%) and uterine rupture in 98 women (7.5\%). Observed frequencies for abnormally invasive placenta indication varied from 14/73 (19.2\%) in Belgium up to $26 / 52(50 \%)$ in Sweden. Hysterectomy in case of placenta previa only was not performed at all in Belgium and Denmark while this was the indication in 41/276 (14.9\%) of women in the UK. Hemorrhage due to cervical lacerations was notably higher in Denmark (6/44) compared to other countries. (Table 3)

Prevalence of peripartum hysterectomy after cesarean section was highest in Italy with 23.2 per 10,000 sections ( $95 \%$ CI 21.1 to 25.6) and lowest in Belgium with 9.0 per 10,000 sections (95\% CI 6.8 - 11.9). Following vaginal birth, prevalence was highest in Slovakia with 4.6 (95\% CI 3.5 - 6.1) and lowest in Sweden with 0.4 per 10,000 births (95\% CI 0.2 - 0.9). Overall relative risk for hysterectomy after cesarean section compared to vaginal birth was 9.1 (95\%CI 8.0-10.4) (Table 4). Relative risk ranged from 2.5 (95\% CI 1.7 - 3.7) in Slovakia to 38.2 (95\% 16.3 - 89.5) in Sweden, in the latter country this being due to a very low incidence after vaginal birth. Due to the unknown number of planned cesarean hysterectomies in case of suspected abnormally invasive placenta, calculations were repeated after excluding women with hysterectomy due to abnormally invasive placenta. Relative risk of peripartum hysterectomy in women who gave birth by cesarean section versus those who gave birth vaginally was 6.8 (95\%CI 5.9-8.0) per 10,000 births (Table S3). There was a strong, positive correlation between national cesarean section rate and prevalence of peripartum hysterectomy $(\rho=0.67, n=9, p<0.05)$ (Figure 2$)$.

Prevalence of peripartum hysterectomy in women with previous cesarean section varied from 10.7 per 10,000 births (95\%CI 7.9 - 14.6) in the Netherlands to 36.7 (95\% CI 31.3 - 43.1) in the UK. In women without previous cesarean section, prevalence varied considerably less ranging from 1.3 per 10,000 births (95\% CI 0.8 - 2.0) in Denmark to 3.7 per 10,000 births in Finland and 
France. Overall relative risk for peripartum hysterectomy in women who had given birth by cesarean section in a previous pregnancy compared to women without a previous cesarean section this was 10.6 (95\% CI 9.4 - 12.1) (Table 5). After excluding women with hysterectomy due to abnormally invasive placenta this relative risk still was 6.4 (95\% CI $5.5-7.6)$ per 10,000 births (Table S4). A statistically non-significant weak correlation was observed between national proportions of women giving birth with a previous cesarean section and national prevalence of pregnancy related hysterectomy $(\rho=0.26, n=8, p=0.5)$ (Figure 3$)$.

\section{DISCUSSION}

The prevalence of peripartum hysterectomy varied significantly in nine European countries. Prevalence was considerably higher in women giving birth by cesarean section and in women who had given birth by cesarean section in a previous pregnancy. Additionally, indications for hysterectomy also varied notably between countries and considerable variance was observed for all reported indications. Such differences may result from differences in women characteristics, national cesarean section rates and national rates of pregnant women with scarred uteri. Such differences may also reflect differences in clinical management of major obstetric hemorrhage between participating countries.

Compared to a systematic review and meta-analysis where weighted prevalence for upper and high income countries was calculated at 7 per 10,000 births, our study demonstrated lower prevalence for all countries except Italy.(10) Another study on emergency peripartum hysterectomy in high income counties, reported prevalence for most European countries lower than 10 per 10,000 births, in line with our results.(8)

We found a nine-fold higher risk of hysterectomy after cesarean section. However, $77 \%$ of women undergoing hysterectomy were delivered by cesarean section and more than half of these were planned. Reason for this may be antenatal diagnosis of placenta previa with or without abnormally invasive placenta in which case vaginal birth is not an option and risk of hysterectomy very high.(27) The number of planned cesarean hysterectomies was not known. Therefore, we repeated calculations after excluding women who had hysterectomy due to abnormally invasive placenta, which was the second most frequent indication among all hysterectomies. In these women, it is the indication for the cesarean section that places them at increased risk of hysterectomy rather than the indication itself. Some of these hysterectomies might in fact have 
been planned before birth. However, even following exclusion of women with abnormally invasive placenta, the prevalence of hysterectomy after cesarean section and in birth following a previous cesarean section both remained significantly higher. Our results are in line with literature, where cesarean section is a strong risk factor for emergency peripartum hysterectomy.(8) Increased risk of hysterectomy after previous cesarean section has been shown before and was demonstrated to be independent of the intended mode of birth. $(8,28)$ As such, the variance of prevalence between countries might to a considerable extent be explained by the difference in national cesarean section rates.

Strength of this study is its unique multi-national character including data from nine nationwide or multi-regional studies. Collaboration between national and multi-regional obstetric survey systems previously led to insights into prevalence and management of uterine rupture.(26) The INOSS collaboration enables collection of considerably robust data regarding rare obstetric diseases.

Main limitations arise from the fact that included studies were performed in different time intervals, over two or three consecutive years with little or no overlap. Obstetric practice and risk factors such as cesarean section rates might have changed over time. $(8,13,29)$ Data stratified by year would reflect differences between studies rather than being indicative of changes in practice over time. However, pooling data from recent and older studies showed a marked difference in prevalence of hysterectomy which, in light of other evidence, may be the result of rising cesarean section rates. Furthermore, there were 40 registered hysterectomies with missing information on gestational age. Given the fact that only $1 \%$ of all hysterectomies in the database were excluded due to a gestational age below 22 weeks, we opted that excluding these cases would lead to exclusion of actually valid cases, which would lead to underestimation of prevalence. Also, a previous cesarean section is strongly associated with birth by cesarean in the index pregnancy. In the calculation of the correlation between prevalence of hysterectomy and mode of birth, previous cesarean section should be taken into consideration. As such, calculation of adjusted relative risks for each exposure, would have led to better estimation of the independent role of each of them. However, for the background data we only had aggregate numbers for mode of birth and for previous cesarean section and could not perform such analysis. Accordingly, in the correlation of prevalence of peripartum hysterectomy with previous cesarean section, taking parity into account would lead to more valid results. Also, the number of previous cesarean sections adds up to the risk of hysterectomy and other serious morbidity with every additional operation as previously 
described.(9) Unfortunately, in our database we only had access to binary information on presence of a previous cesarean section. Therefore, the effect of number of previous cesareans was not measured. Another limitation is the fact that case identification and study objectives differed between countries. Seven of nine studies were designed specifically to report peripartum hysterectomy while the studies from the Netherlands and France included women with severe maternal morbidity. In Slovakia, data were collected retrospectively, which may have led to some underreporting. Nonetheless, their numbers still gave them the second highest prevalence; actual prevalence may even have been higher.

In order to enhance comparability of national survey studies, collectively designed surveillance studies using uniform criteria are required and INOSS may provide an important platform to perform such studies. In addition, use of a uniform definition for upcoming studies is important. Therefore, INOSS proposed a definition of 'pregnancy-related hysterectomy' using a Delphi process:(1) "Surgical removal of the uterus during pregnancy or up to 42 days postpartum". This definition is wide enough to include all indications and pregnancy intervals. Since our specific study includes only a subset of women who had a hysterectomy around the time of birth, we decided to apply the common terminology 'peripartum hysterectomy' in this paper. Streamlining multiple national surveys is necessary to overcome problems related to different study intervals.

\section{CONCLUSION}

Prevalence of peripartum hysterectomy varied widely between countries and was higher in countries with higher cesarean section rates. Commonest indications were uterine atony and abnormally invasive placenta. Rate of peripartum hysterectomy was considerably higher in women who gave birth by cesarean section as well as in women with a previous cesarean section. Further investigation is necessary in order to fully understand the underlying factors that contribute to these differences. Further work is needed to determine optimal management strategies and comparison of those between countries.

\section{Acknowledgments}

We thank Mrs. Bente Elgersma for her contribution to building the database. The Netherlands: NethOSS board Kitty Bloemenkamp (also INOSS chair), Jos van Roosmalen, Timme Schaap, 
Thomas van den Akker, Joost Zwart. We would like to acknowledge all clinicians reporting data to the LEMMoN study between 2004 and 2006. Italy: We would like to acknowledge all clinicians reporting data to the ItOSS study. Finland: Kati Ojala (Oulu University Hospital); Maija-Riitta Ordén (Kuopio University Hospital), Nanneli Pallasmaa (Turku University Hospital) and Outi Palomäki (Tampere University Hospital), Anna-Maija Tapper (HUCH Hyvinkää Hospital), Outi Äyräs (Helsinki Univeristy Hospital). Sweden: Karin Källén, Karin Gottvall and all clinicians reporting to the NOSS study between 2009 to 2011. France: Epimoms study, all clinicians and research staff who contributed to case identification and data collection.

We also want to thank all clinicians who contributed to case identification and data collection in the UK, Denmark, Slovakia and Belgium. Permission has been obtained from all named persons.

\section{References}

1. Schaap T, Bloemenkamp K, Deneux-Tharaux C, et al. Defining definitions: a Delphi study to develop a core outcome set for conditions of severe maternal morbidity. BJOG. 2019;126:394-401. 2. Evaluating the quality of care for severe pregnancy complications: the WHO near-miss approach for maternal health. http:// apps. who. int/ iris/ bitstream/10665/ 44692/ 1/9789241502221_eng. pdf 2011. 3. Flood KM, Said S, Geary M, Robson M, Fitzpatrick C, Malone FD. Changing trends in peripartum hysterectomy over the last 4 decades. Am J Obstet Gynecol. 2009;200:632 e1-6.

4. Huque S, Roberts I, Fawole B, Chaudhri R, Arulkumaran S, Shakur-Still H. Risk factors for peripartum hysterectomy among women with postpartum haemorrhage: analysis of data from the WOMAN trial. BMC Pregnancy Childbirth. 2018;18:186.

5. Whiteman MK, Kuklina E, Hillis SD, et al. Incidence and determinants of peripartum hysterectomy. Obstet Gynecol. 2006;108:1486-92.

6. Kwee A, Bots ML, Visser GH, Bruinse HW. Emergency peripartum hysterectomy: A prospective study in The Netherlands. Eur J Obstet Gynecol Reprod Biol. 2006;124:187-92.

7. Sakse A, Weber T, Nickelsen C, Secher NJ. Peripartum hysterectomy in Denmark 1995-2004. Acta Obstet Gynecol Scand. 2007;86:1472-5.

8. de la Cruz CZ, Thompson EL, O'Rourke K, Nembhard WN. Cesarean section and the risk of emergency peripartum hysterectomy in high-income countries: a systematic review. Arch Gynecol Obstet. 2015;292:1201-15.

9. Silver RM, Landon MB, Rouse DJ, Leveno KJ, Spong CY, Thom EA, et al. Maternal morbidity associated with multiple repeat cesarean deliveries. Obstet Gynecol. 2006;107:1226-32.

This article is protected by copyright. All rights reserved 
10. van den Akker T, Brobbel C, Dekkers OM, Bloemenkamp KW. Prevalence, Indications, Risk Indicators, and Outcomes of Emergency Peripartum Hysterectomy Worldwide: A Systematic Review and Meta-analysis. Obstet Gynecol. 2016;128:1281-94.

11. Jakobsson M, Tapper AM, Colmorn LB, et al. Emergency peripartum hysterectomy: results from the prospective Nordic Obstetric Surveillance Study (NOSS). Acta Obstet Gynecol Scand. 2015;94:745-54. 12. Knight M, Ukoss. Peripartum hysterectomy in the UK: management and outcomes of the associated haemorrhage. BJOG. 2007;114:1380-7.

13. Vandenberghe G, Guisset M, Janssens I, et al. A nationwide population-based cohort study of peripartum hysterectomy and arterial embolisation in Belgium: results from the Belgian Obstetric Surveillance System. BMJ Open. 2017;7:e016208.

14. Zwart JJ, Dijk PD, van Roosmalen J. Peripartum hysterectomy and arterial embolization for major obstetric hemorrhage: a 2-year nationwide cohort study in the Netherlands. Am J Obstet Gynecol. 2010;202:150 e1-7.

15. Kristufkova A, Krobel M, Borovosky M, Danis J, Dugatova M. Analysis of severe acute maternal morbidity in Slovak Republic in year 2012. Gynekol prax. 2015;13:185-91.

16. Knight M, Inoss. The International Network of Obstetric Survey Systems (INOSS): benefits of multi-country studies of severe and uncommon maternal morbidities. Acta Obstet Gynecol Scand. 2014;93:127-31.

17. Kristufkova A, Krobel M, Danis J, Dugatova M, Nemethova B, Borovosky M. Analysis of severe acute maternal morbidity in Slovak Republic in year 2013. Gynekol prax. 2016;14:92-8.

18. Kristufkova A, Krobel M, Danis J, Dugatova M, Nemethova B, Borovosky M. Analysis of severe acute maternal morbidity in Slovak Republic in year 2014. Gynekol prax. 2017;15:25-32.

19. Maraschini A, Lega I, D'Aloja P, et al. Women undergoing peripartum hysterectomy due to obstetric hemorrhage: a prospective population based study. Acta Obstet Gynecol Scand. 2020;99:274-282. 20. Colmorn LB, Petersen KB, Jakobsson M, et al. The Nordic Obstetric Surveillance Study: a study of complete uterine rupture, abnormally invasive placenta, peripartum hysterectomy, and severe blood loss at delivery. Acta Obstet Gynecol Scand. 2015;94:734-44.

21. Blondel B, Coulm B, Bonnet C, Goffinet F, Le Ray C, National Coordination Group of the National Perinatal S. Trends in perinatal health in metropolitan France from 1995 to 2016: Results from the French National Perinatal Surveys. J Gynecol Obstet Hum Reprod. 2017;46:701-13.

22. Zwart JJ, Richters JM, Ory F, de Vries JI, Bloemenkamp KW, van Roosmalen J. Severe maternal morbidity during pregnancy, delivery and puerperium in the Netherlands: a nationwide population-based study of 371,000 pregnancies. BJOG. 2008;115:842-50. 
23. Vandenberghe G, Roelens K, Van Leeuw V, Englert Y, Hanssens M, Verstraelen H. The Belgian Obstetric Surveillance System to monitor severe maternal morbidity. Facts Views Vis Obgyn. 2017;9:1818.

24. Knight M, Kurinczuk JJ, Tuffnell D, Brocklehurst P. The UK Obstetric Surveillance System for rare disorders of pregnancy. BJOG. 2005;112:263-5.

25. Madar H, Goffinet F, Seco A, Rozenberg P, Dupont C, Deneux-Tharaux C. Severe Acute Maternal Morbidity in Twin Compared With Singleton Pregnancies. Obstet Gynecol. 2019;133:1141-50.

26. Vandenberghe G, Bloemenkamp K, Berlage S, et al. The International Network of Obstetric Survey Systems study of uterine rupture: a descriptive multi-country population-based study. BJOG. 2019;126:370-381.

27. Jauniaux E, Bunce C, Gronbeck L, Langhoff-Roos J. Prevalence and main outcomes of placenta accreta spectrum: a systematic review and metaanalysis. Am J Obstet Gynecol. 2019;221:208-218. 28. Colmorn LB, Krebs L, Klungsoyr K, et al. Mode of first delivery and severe maternal complications in the subsequent pregnancy. Acta Obstet Gynecol Scand. 2017;96:1053-62.

29. Boerma T, Ronsmans C, Melesse DY, et al. Global epidemiology of use of and disparities in cesarean sections. Lancet. 2018;392:1341-8. 


\section{Supporting Information Legends}

Table S1. Methodology of case collection for each participating country and summary of background data of total number of births.

Table S2. National definitions of peripartum hysterectomy.

Table S3. Relative risk of peripartum hysterectomy for cesarean section compared to vaginal birth after excluding hysterectomies due to abnormally invasive placenta. ${ }^{a} \mathrm{PRH}$ : peripartum hysterectomy, ${ }^{\mathrm{b}} \mathrm{CI}$ : Confidence Interval, *Prevalence per 10000 births or cesarean sections.

Table S4. Relative risk of peripartum hysterectomy for women with a history of previous cesarean section compared women without previous cesarean section after excluding hysterectomies due to abnormally invasive placenta. ${ }^{\text {a }} \mathrm{PRH}$ : peripartum hysterectomy, ${ }^{\mathrm{b}} \mathrm{CI}$ : Confidence Interval , * Prevalence per 10,000 births.

\section{Legends of figures and tables}

Figure 1. Prevalence of peripartum hysterectomy.

Figure 2. Correlation of prevalence of peripartum hysterectomy with national cesarean section rates. * PRH = peripartum hysterectomy

Figure 3. Correlation of prevalence of peripartum hysterectomy with national rates of women with previous cesarean section. * $\mathrm{PRH}=$ peripartum hysterectomy

Table 1. Prevalence of peripartum hysterectomy using national definitions and after use of uniform definition.

PRH: Peripartum hysterectomy, CI: Confidence interval 
Table 2. Maternal and pregnancy characteristics at time of peripartum hysterectomy. All data are presented as $\mathrm{n}(\%)$ or mean \pm standard deviation unless otherwise specified. Percentages are calculated after subtracting missings.

* Presented as percentage of number of cesarean sections.

BMI, Body mass index; BEL: Belgium; DEN: Denmark; FIN: Finland; FRA: France; UK: United Kingdom; ITA: Italy; NL: The Netherlands; SVK: Slovakia; SWE: Sweden.

Table 3. Most important indication for peripartum hysterectomy presented as $\mathrm{n}(\%)$.

Table 4. Relative risk of peripartum hysterectomy for cesarean section compared to vaginal birth. *Prevalence per 10000 births or cesarean sections.

PRH: peripartum hysterectomy, CS: Cesarean sections, CI: Confidence Interval,

Table 5. Relative Risk of peripartum hysterectomy for women with versus without previous cesarean section.

*Prevalence per 10000 births or cesarean sections.

PRH: peripartum hysterectomy, CI: Confidence Interval, 


\begin{tabular}{|c|c|c|c|c|c|}
\hline Countries (study) & PRH $^{a}$ (n) & Births (n) & $\begin{array}{l}\text { Prevalence per } \\
10000 \text { births } \\
(95 \% \text { CI })\end{array}$ & $\begin{array}{l}\text { PRH }^{\text {a }} \\
\text { uniform } \\
\text { definition } \\
\text { (n) }\end{array}$ & $\begin{array}{l}\text { Prevalence - } \\
\text { uniform definition } \\
\text { per } 10000 \text { births } \\
\left(95 \% \mathrm{CI}^{\mathrm{b}}\right)\end{array}$ \\
\hline $\begin{array}{l}\text { Denmark (NOSS) } \\
\text { Apr '09 - Dec '11 }\end{array}$ & 50 & 168170 & $\begin{array}{c}3.0 \\
(2.3-3.9)\end{array}$ & 44 & $\begin{array}{c}2.6 \\
(2.0-3.5)\end{array}$ \\
\hline $\begin{array}{l}\text { Netherlands } \\
\text { (LEMMon) }\end{array}$ & 110 & 358874 & $\begin{array}{c}3.1 \\
(2.5-3.7)\end{array}$ & 95 & $\begin{array}{c}2.7 \\
(2.2-3.2)\end{array}$ \\
\hline $\begin{array}{l}\text { Belgium (B.OSS) } \\
\text { Jan '12 - Dec '13 }\end{array}$ & 84 & 252272 & $\begin{array}{c}3.3 \\
(2.7-4.1)\end{array}$ & 73 & $\begin{array}{c}2.9 \\
(2.3-3.6)\end{array}$ \\
\hline $\begin{array}{l}\text { Sweden (NOSS) } \\
\text { Sep '09 - Aug '11 }\end{array}$ & 52 & 175575 & $\begin{array}{c}3.0 \\
(2.3-3.9)\end{array}$ & 52 & $\begin{array}{c}3.0 \\
(2.3-3.9)\end{array}$ \\
\hline $\begin{array}{l}\text { UK (UKOSS) } \\
\text { Feb '05 - Feb '06 }\end{array}$ & 315 & 609300 & $\begin{array}{c}5.2 \\
(4.6-5.8)\end{array}$ & 276 & $\begin{array}{c}4.5 \\
(4.0-5.0)\end{array}$ \\
\hline $\begin{array}{l}\text { Finland (NOSS) } \\
\text { Apr '09 - Aug '11 }\end{array}$ & 74 & 145546 & $\begin{array}{c}5.1 \\
(4.1-6.4)\end{array}$ & 72 & $\begin{array}{c}5.0 \\
(3.9-6.2)\end{array}$ \\
\hline $\begin{array}{l}\text { France } \\
\text { (EPIMOMS) }\end{array}$ & 104 & 182309 & $\begin{array}{c}5.7 \\
(4.7-6.9)\end{array}$ & 98 & $\begin{array}{c}5.4 \\
(4.4-6.6)\end{array}$ \\
\hline $\begin{array}{l}\text { Slovakia (SOSS) } \\
\text { Jan'12 - Dec '14 }\end{array}$ & 104 & 146972 & $\begin{array}{c}7.1 \\
(5.8-8.6)\end{array}$ & 103 & $\begin{array}{c}7.0 \\
(5.8-8.5)\end{array}$ \\
\hline Italy (ITOSS) & 500 & 458995 & 10.9 & 489 & 10.7 \\
\hline
\end{tabular}




\begin{tabular}{|l|l|l|l|l|r|}
\hline Sep '14 - Aug'16 & & & $(10.0-11.9)$ & & $(9.8-11.6)$ \\
\hline Total & 1393 & 2498013 & & 1302 & 5.2 \\
& & & & & $(4.9-5.5)$ \\
\hline
\end{tabular}

Table 1. Prevalence of peripartum hysterectomy using national definitions and after use of uniform definition. ${ }^{\mathrm{a}} \mathrm{PRH}$ : Peripartum hysterectomy, ${ }^{\mathrm{b}} \mathrm{CI}$ : Confidence interval. 


\begin{tabular}{|c|c|c|c|c|c|c|c|c|c|c|}
\hline $32+0-36+6$ & $\begin{array}{c}23 \\
(31.5)\end{array}$ & $\begin{array}{c}13 \\
(29.5)\end{array}$ & $\begin{array}{c}20 \\
(27.8)\end{array}$ & $\begin{array}{c}22 \\
(22.4)\end{array}$ & $\begin{array}{c}80 \\
(29.5)\end{array}$ & $\begin{array}{c}166 \\
(36.2)\end{array}$ & $\begin{array}{c}16 \\
(16.8)\end{array}$ & $\begin{array}{c}26 \\
(25.7)\end{array}$ & $\begin{array}{c}21 \\
(40.4)\end{array}$ & $\begin{array}{c}387 / 992 \\
(30.7)\end{array}$ \\
\hline$\geq 37+0$ & $\begin{array}{c}40 \\
(54.8)\end{array}$ & $\begin{array}{c}29 \\
(65.9)\end{array}$ & $\begin{array}{c}48 \\
(66.7)\end{array}$ & $\begin{array}{c}69 \\
(70.4)\end{array}$ & $\begin{array}{c}167 \\
(61.6)\end{array}$ & $\begin{array}{r}259 \\
(56.6)\end{array}$ & $\begin{array}{c}73 \\
(76.8)\end{array}$ & $\begin{array}{c}62 \\
(61.4)\end{array}$ & $\begin{array}{c}28 \\
(53.8)\end{array}$ & $\begin{array}{c}775 / 992 \\
(61.4)\end{array}$ \\
\hline Missing $\mathrm{n}(\%)$ & $0(0.0)$ & $0(0.0)$ & $0(0.0)$ & $0(0.0)$ & $5(1.8)$ & $31(6.3)$ & $0(0.0)$ & $4(3.9)$ & $0(0.0)$ & $40(3.1)$ \\
\hline $\begin{array}{l}\text { Previous } \\
\text { caesarean }\end{array}$ & $(50.0)$ & $(56.8)$ & $(33.3)$ & $(37.9)$ & $(54.0)$ & 228 & $\begin{array}{c}40 \\
(42.1)\end{array}$ & $\begin{array}{c}20 \\
(83.3)\end{array}$ & $\begin{array}{c}28 \\
(53.8)\end{array}$ & $\begin{array}{c}\mathbf{5 8 6} / 1177 \\
(49.8)\end{array}$ \\
\hline Missing $\mathrm{n}(\%)$ & $1(1.4)$ & $0(0.0)$ & $0(0.0)$ & $3(3.1)$ & $0(0.0)$ & $42(8.6)$ & $0(0.0)$ & 79 (76.7) & $0(0.0)$ & $125(9.6)$ \\
\hline
\end{tabular}

Table 2. Maternal and pregnancy characteristics at time of peripartum hysterectomy. All data are presented as $\mathrm{n}(\%)$ or mean \pm standard deviation unless otherwise specified. Percentages are calculated after subtracting missings. * Presented as percentage of number of caesarean sections. ${ }^{\mathrm{a}}$ BEL: Belgium; ${ }^{\mathrm{b}}$ DEN: Denmark; ${ }^{\mathrm{c}}$ FIN: Finland; ${ }^{\mathrm{d}}$ FRA: France; ${ }^{\mathrm{e}}$ UK: United Kingdom; ${ }^{\mathrm{f}}$ ITA: Italy; ${ }^{\mathrm{g}}$ NL: The Netherlands; ${ }^{\mathrm{h}} \mathrm{SVK}$ : Slovakia; ${ }^{\mathrm{i}} \mathrm{SWE}$ : Sweden. ${ }^{\mathrm{j}}$ Body mass index. 


\begin{tabular}{|c|c|c|c|c|c|c|c|c|c|c|}
\hline $\begin{array}{l}\text { Indications of } \\
\text { hysterectomy }\end{array}$ & $\begin{array}{l}\text { Belgium } \\
(n=73)\end{array}$ & $\begin{array}{l}\text { Denmark } \\
(n=44)\end{array}$ & $\begin{array}{l}\text { Finland } \\
(n=72)\end{array}$ & $\begin{array}{l}\text { France } \\
\text { (n=98) }\end{array}$ & $\begin{array}{l}\text { UK } \\
(n=276)\end{array}$ & $\begin{array}{l}\text { Italy } \\
\text { (n=489) }\end{array}$ & $\begin{array}{l}\text { Netherlands } \\
\text { (n=95) }\end{array}$ & $\begin{array}{l}\text { Slovakia } \\
(n=103)\end{array}$ & $\begin{array}{l}\text { Sweden } \\
(n=52)\end{array}$ & $\begin{array}{l}\text { Total } \\
\text { (n=1302) }\end{array}$ \\
\hline Uterine atony & $\begin{array}{l}29 \\
(39.7 \%)\end{array}$ & $\begin{array}{l}12 \\
(27.3 \%)\end{array}$ & $\begin{array}{l}17 \\
(23.6 \%)\end{array}$ & $\begin{array}{l}42 \\
(42.9 \%)\end{array}$ & $\begin{array}{l}98 \\
(35.5 \%)\end{array}$ & $\begin{array}{l}199 \\
(40.7 \%)\end{array}$ & $\begin{array}{l}34 \\
(35.8 \%)\end{array}$ & $\begin{array}{l}18 \\
(17.5 \%)\end{array}$ & $\begin{array}{l}10 \\
(19.2 \%)\end{array}$ & 459 (35.3\%) \\
\hline $\begin{array}{l}\text { Abnormally } \\
\text { invasive } \\
\text { placenta }\end{array}$ & $\begin{array}{l}14 \\
(19.2 \%)\end{array}$ & $\begin{array}{l}17 \\
(38.6 \%)\end{array}$ & $\begin{array}{l}16 \\
(22.2 \%)\end{array}$ & $\begin{array}{l}23 \\
(23.5 \%)\end{array}$ & $\begin{array}{l}103 \\
(37.3 \%)\end{array}$ & $\begin{array}{l}188 \\
(38.4 \%)\end{array}$ & $\begin{array}{l}36 \\
(37.9 \%)\end{array}$ & $\begin{array}{l}30 \\
(29.1 \%)\end{array}$ & $\begin{array}{l}26 \\
(50 \%)\end{array}$ & 453 (34.8\%) \\
\hline Uterine ru & $\begin{array}{l}10 \\
(13.7 \%)\end{array}$ & $\begin{array}{l}2 \\
(4.5 \%)\end{array}$ & $\begin{array}{l}17 \\
(23.6 \%)\end{array}$ & $\begin{array}{l}9 \\
(9.2 \%)\end{array}$ & $\begin{array}{l}17 \\
(6.2 \%)\end{array}$ & $\begin{array}{l}14 \\
(2.9 \%)\end{array}$ & $\begin{array}{l}10 \\
(10.5 \%)\end{array}$ & $\begin{array}{l}16 \\
(15.5 \%)\end{array}$ & $\begin{array}{l}3 \\
(5.8 \%)\end{array}$ & 98 (7.5\%) \\
\hline $\begin{array}{l}\text { Unspecified } \\
\text { Hemorrhage }\end{array}$ & $\begin{array}{l}5 \\
(6.8 \%)\end{array}$ & 0 & $\begin{array}{l}11 \\
(15.3 \%)\end{array}$ & $\begin{array}{l}2 \\
(2 \%)\end{array}$ & 0 & $\begin{array}{l}44 \\
(9 \%)\end{array}$ & $\begin{array}{l}8 \\
(8.4 \%)\end{array}$ & $\begin{array}{l}16 \\
(15.5 \%)\end{array}$ & $\begin{array}{l}7 \\
(13.5 \%)\end{array}$ & 93 (7.1\%) \\
\hline Placenta previa & 0 & 0 & $\begin{array}{l}9 \\
(12.5 \%)\end{array}$ & $\begin{array}{l}2 \\
(2 \%)\end{array}$ & $\begin{array}{l}41 \\
(14.9 \%)\end{array}$ & $\begin{array}{l}15 \\
(3.1 \%)\end{array}$ & $\begin{array}{l}4 \\
(4.2 \%)\end{array}$ & $\begin{array}{l}11 \\
(10.7 \%)\end{array}$ & $\begin{array}{l}2 \\
(3.8 \%)\end{array}$ & $84(6.5 \%)$ \\
\hline $\begin{array}{l}\text { Placental } \\
\text { abruption }\end{array}$ & 0 & $\begin{array}{l}2 \\
(4.5 \%)\end{array}$ & 0 & $\begin{array}{l}6 \\
(6.1 \%)\end{array}$ & $\begin{array}{l}2 \\
(0.7 \%)\end{array}$ & $\begin{array}{l}20 \\
(4.1 \%)\end{array}$ & 0 & $\begin{array}{l}2 \\
(1.9 \%)\end{array}$ & $\begin{array}{l}2 \\
(3.9 \%)\end{array}$ & $34(2.6 \%)$ \\
\hline $\begin{array}{l}\text { Cerv } \\
\text { lacer }\end{array}$ & 0 & $\begin{array}{l}6 \\
(13.6 \%)\end{array}$ & $\begin{array}{l}2 \\
(2.8 \%)\end{array}$ & 0 & $\begin{array}{l}2 \\
(0.7 \%)\end{array}$ & $4(0.8 \%)$ & $\begin{array}{l}1 \\
(1.1 \%)\end{array}$ & 0 & 0 & 15 (1.2\%) \\
\hline Fibr & 0 & $\begin{array}{l}2 \\
(4.5 \%)\end{array}$ & 0 & 0 & $\begin{array}{l}1 \\
(0.4 \%)\end{array}$ & $\begin{array}{l}2 \\
(0.4 \%)\end{array}$ & $\begin{array}{l}1 \\
(1.1 \%)\end{array}$ & 0 & $\begin{array}{l}2 \\
(3.8 \%)\end{array}$ & $8(0.6 \%)$ \\
\hline DIC & 0 & 0 & 0 & $\begin{array}{l}6 \\
(6.1 \%)\end{array}$ & $\begin{array}{l}1 \\
(0.4 \%)\end{array}$ & $\begin{array}{l}1 \\
(0.2 \%)\end{array}$ & 0 & 0 & 0 & $8(0.6 \%)$ \\
\hline Infection & 0 & 0 & 0 & $\begin{array}{l}1 \\
(1 \%)\end{array}$ & 0 & 0 & $\begin{array}{l}1 \\
(1.1 \%)\end{array}$ & 0 & 0 & $2(0.2 \%)$ \\
\hline Other & $\begin{array}{l}2 \\
(2.7 \%)\end{array}$ & $\begin{array}{l}3 \\
(6.8 \%)\end{array}$ & 0 & $\begin{array}{l}7 \\
(7.1 \%)\end{array}$ & $\begin{array}{l}8 \\
(2.9 \%)\end{array}$ & $\begin{array}{l}2 \\
(0.4 \%)\end{array}$ & 0 & $\begin{array}{l}3 \\
(2.9 \%)\end{array}$ & 0 & 25 (1.9\%) \\
\hline Missing & 13 & 0 & 0 & 0 & 3 & 0 & 0 & 7 & 0 & $23(1.8 \%)$ \\
\hline
\end{tabular}




\begin{tabular}{|l|l|l|l|l|l|l|l|l|l|l|}
\hline & $(17.8 \%)$ & & & & $(1.1 \%)$ & & & $(6.8 \%)$ & & \\
\hline
\end{tabular}

Table 3. Most important indication for peripartum hysterectomy presented as $\mathrm{n}(\%)$. 


\begin{tabular}{|c|c|c|c|c|c|c|c|c|}
\hline \multirow{2}{*}{ Country } & \multirow{2}{*}{$\begin{array}{c}\text { Caesarean } \\
\text { section } \\
\text { rate }(\%)\end{array}$} & \multicolumn{3}{|c|}{ Caesarean section } & \multicolumn{3}{|c|}{ Vaginal birth } & \multirow{2}{*}{$\begin{array}{c}\text { Relative } \\
\text { risk }\end{array}$} \\
\hline & & $\begin{array}{l}\text { Number } \\
\text { of PRH }{ }^{\mathrm{a}}\end{array}$ & $\begin{array}{l}\text { Number } \\
\text { of CS }\end{array}$ & $\begin{array}{l}\text { Prevalence* } \\
\left(95 \% \mathrm{CI}^{\mathrm{c}}\right)\end{array}$ & $\begin{array}{l}\text { Number } \\
\text { of } \mathrm{PRH}\end{array}$ & $\begin{array}{c}\text { Number } \\
\text { of vaginal } \\
\text { births }\end{array}$ & $\begin{array}{c}\text { Prevalence* } \\
(95 \% \mathrm{CI})\end{array}$ & \\
\hline Belgium & 21.5 & 49 & 54369 & $\begin{array}{c}9.0 \\
(6.8-11.9)\end{array}$ & 23 & 197903 & $\begin{array}{c}1.2 \\
(0.7-1.7)\end{array}$ & $\begin{array}{c}7.8 \\
(4.7-12.7)\end{array}$ \\
\hline Denmark & 21.3 & 36 & 35821 & $\begin{array}{c}10.1 \\
(7.3-13.9)\end{array}$ & 8 & 132349 & $\begin{array}{c}0.6 \\
(0.3-1.2)\end{array}$ & $\begin{array}{c}16.6 \\
(7.7-35.8)\end{array}$ \\
\hline Finland & 16.2 & 52 & 23542 & $\begin{array}{c}22.1 \\
(16.9-29.0)\end{array}$ & 20 & 122004 & $\begin{array}{c}1.6 \\
(1.1-2.6)\end{array}$ & $\begin{array}{c}13.5 \\
(8.0-22.6)\end{array}$ \\
\hline France & 21.5 & 67 & 39194 & $\begin{array}{c}17.1 \\
(13.5-21.7)\end{array}$ & 31 & 143115 & $\begin{array}{c}2.2 \\
(1.5-3.1)\end{array}$ & $\begin{array}{c}7.9 \\
(5.2-12.1)\end{array}$ \\
\hline Italy & 38.5 & 410 & 176713 & $\begin{array}{c}23.2 \\
(21.1-25.6)\end{array}$ & 75 & 282282 & $\begin{array}{c}2.6 \\
(2.1-3.3)\end{array}$ & $\begin{array}{c}8.8 \\
(6.8-11.2)\end{array}$ \\
\hline $\begin{array}{c}\text { The } \\
\text { Netherlands }\end{array}$ & 15.0 & 59 & 53762 & $\begin{array}{c}11.0 \\
(8.5-14.2)\end{array}$ & 36 & 305112 & $\begin{array}{c}1.2 \\
(0.9-1.6)\end{array}$ & $\begin{array}{c}9.3 \\
(6.1-14.1)\end{array}$ \\
\hline Slovakia & 30.5 & 51 & 44826 & $\begin{array}{c}11.4 \\
(8.7-15.0)\end{array}$ & 47 & 102146 & $\begin{array}{c}4.6 \\
(3.5-6.1)\end{array}$ & $\begin{array}{c}2.5 \\
(1.7-3.7)\end{array}$ \\
\hline Sweden & 16.7 & 46 & 29327 & $\begin{array}{c}15.7 \\
(11.8-20.9)\end{array}$ & 6 & 146248 & $\begin{array}{c}0.4 \\
(0.2-0.9)\end{array}$ & $\begin{array}{c}38.2 \\
(16.3-89.5)\end{array}$ \\
\hline $\begin{array}{c}\text { United } \\
\text { Kingdom }\end{array}$ & 23.5 & 226 & 143185 & $\begin{array}{c}15.8 \\
(13.9-18.0)\end{array}$ & 50 & 466115 & $\begin{array}{c}1.1 \\
(0.8-1.4)\end{array}$ & $\begin{array}{c}14.7 \\
(10.8-20.0)\end{array}$ \\
\hline Total & 24.0 & 996 & 600739 & & 296 & 1897274 & & $\begin{array}{c}9.1 \\
(8.0-10.4)\end{array}$ \\
\hline
\end{tabular}

Table 4. Relative risk of peripartum hysterectomy for caesarean section compared to vaginal birth. ${ }^{\mathrm{a}} \mathrm{PRH}$ : peripartum hysterectomy, ${ }^{\mathrm{b}} \mathrm{CS}$ : Caesarean sections, ${ }^{\mathrm{c}} \mathrm{CI}$ : Confidence Interval, *Prevalence per 10000 births or caesarean sections. 


\begin{tabular}{|c|c|c|c|c|c|c|c|c|}
\hline & & With pr & jious cae & arean section & With & $\begin{array}{r}\text { previous } \\
\text { section }\end{array}$ & aesarean & \\
\hline Country & $\begin{array}{c}\text { with } \\
\text { previous } \\
\text { CS }\end{array}$ & $\begin{array}{l}\mathrm{PRH}^{\mathrm{a}} \\
(\mathrm{n})\end{array}$ & $\begin{array}{c}\text { Births } \\
\text { (n) }\end{array}$ & $\begin{array}{l}\text { Prevalence } \\
(95 \% \mathrm{CI}) *\end{array}$ & $\begin{array}{l}\mathrm{PRH}^{\mathrm{a}} \\
\text { (n) }\end{array}$ & $\begin{array}{l}\text { Births } \\
\text { (n) }\end{array}$ & $\begin{array}{c}\text { Prevalence } \\
\left(95 \% \mathrm{CI}^{\mathrm{b}}\right) \\
*\end{array}$ & Relative risk \\
\hline Belgium & 10.7 & 36 & 27007 & $\begin{array}{c}13.3 \\
(9.6-18.5)\end{array}$ & 36 & 225265 & $\begin{array}{c}1.6 \\
(1.2-2.2)\end{array}$ & $\begin{array}{c}8.3 \\
(5.3-13.2)\end{array}$ \\
\hline Denmark & 11.6 & 25 & 19626 & $\begin{array}{c}12.7 \\
(8.6-18.8)\end{array}$ & 19 & 148544 & $\begin{array}{c}1.3 \\
(0.8-2.0)\end{array}$ & $\begin{array}{c}10.0 \\
(5.5-18.1)\end{array}$ \\
\hline Finland & 9.7 & 24 & 14167 & $\begin{array}{c}16.9 \\
(11.4-25.2)\end{array}$ & 48 & 131379 & $\begin{array}{c}3.7 \\
(2.8-4.8)\end{array}$ & $\begin{array}{c}4.6 \\
(2.8-7.6)\end{array}$ \\
\hline France & 12.3 & 36 & 22424 & $\begin{array}{c}16.1 \\
(11.6-22.2)\end{array}$ & 59 & 159885 & $\begin{array}{c}3.7 \\
(2.9-4.8)\end{array}$ & $\begin{array}{c}4.4 \\
(2.9-6.6)\end{array}$ \\
\hline Italy & 16.8 & 228 & 77111 & $\begin{array}{c}29.6 \\
(25.9-33.7)\end{array}$ & 74 & 381884 & $\begin{array}{c}1.9 \\
(1.5-2.4)\end{array}$ & $\begin{array}{c}13.9 \\
(10.7-18.1)\end{array}$ \\
\hline Netherlands & 10.4 & 40 & 37343 & $\begin{array}{c}10.7 \\
(7.9-14.6)\end{array}$ & 55 & 321531 & $\begin{array}{c}1.7 \\
(1.3-2.2)\end{array}$ & $\begin{array}{c}6.3 \\
(4.2-9.4)\end{array}$ \\
\hline Slovakia & & & & Data $n$ & $t$ availa & & & \\
\hline Sweden & 8.9 & 28 & 15698 & $\begin{array}{c}17.8 \\
(12.3-25.8)\end{array}$ & 24 & 159877 & $\begin{array}{c}1.5 \\
(1.0-2.2)\end{array}$ & $\begin{array}{c}11.9 \\
(6.9-20.5)\end{array}$ \\
\hline $\begin{array}{c}\text { United } \\
\text { Kingdom }\end{array}$ & 6.6 & 149 & 40600 & $\begin{array}{c}36.7 \\
(31.3-43.1)\end{array}$ & 127 & 568700 & $\begin{array}{c}2.2 \\
(1.9-2.7)\end{array}$ & $\begin{array}{c}16.4 \\
(13.0-20.8)\end{array}$ \\
\hline Total & 10.9 & 566 & 253976 & & 442 & 2097065 & & $\begin{array}{c}10.6 \\
(9.4-12.1)\end{array}$ \\
\hline
\end{tabular}


Table 5. Relative Risk of peripartum hysterectomy for women with versus without previous caesarean section. ${ }^{a}$ PRH: peripartum hysterectomy, ${ }^{b} \mathrm{CI}$ : Confidence Interval, *Prevalence per 10000 births or caesarean sections. 


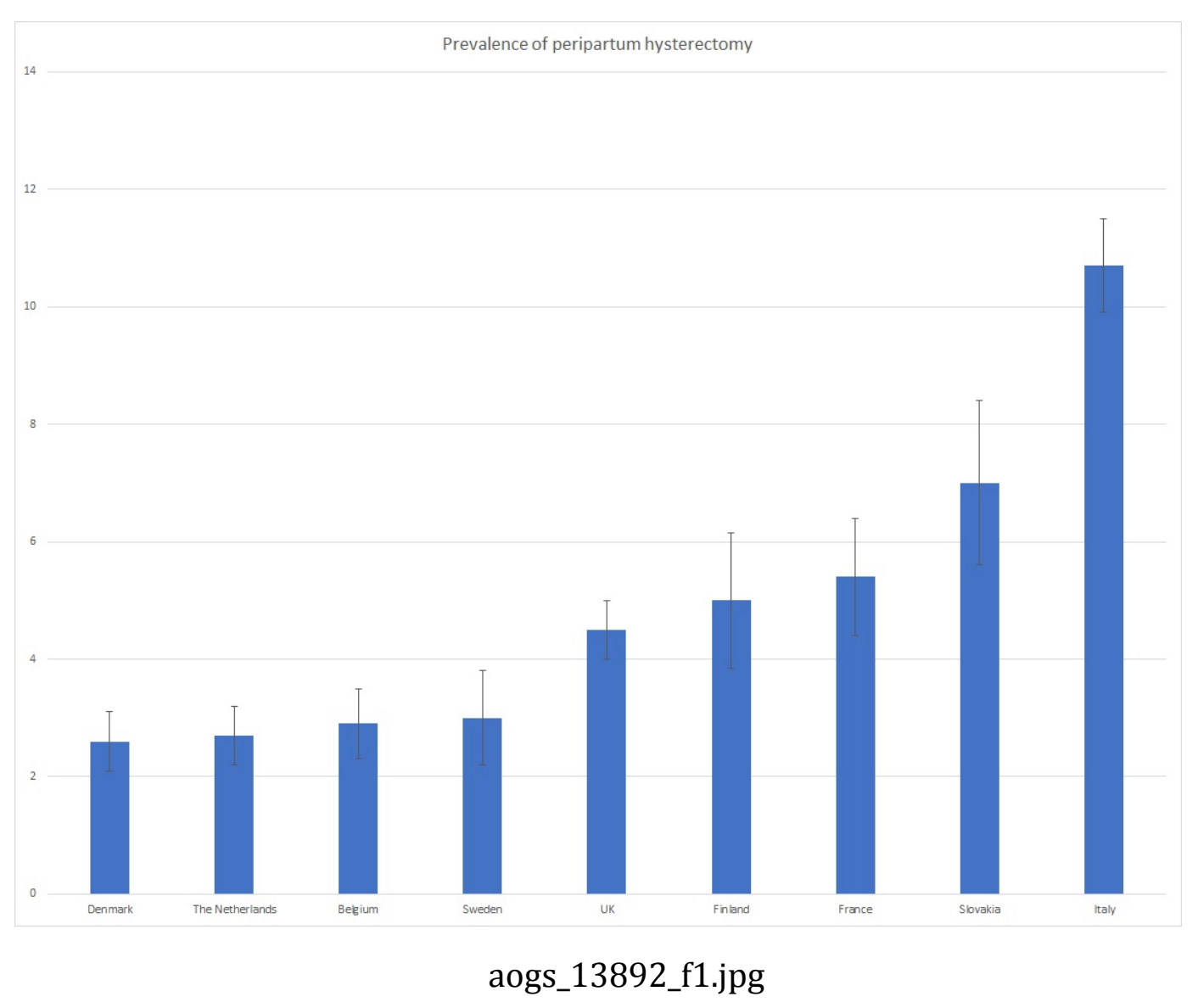

This article is protected by copyright. All rights reserved 


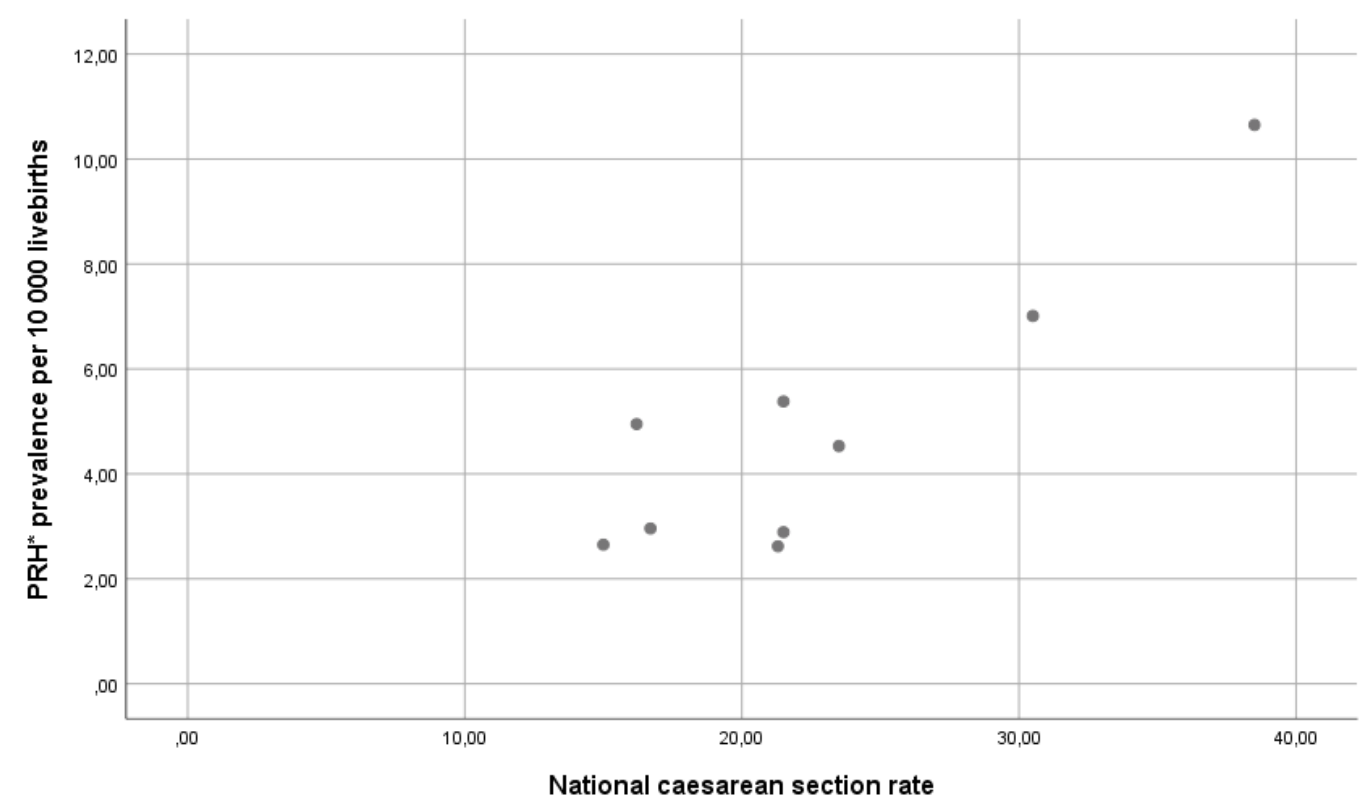

aogs_13892_f2.tif 


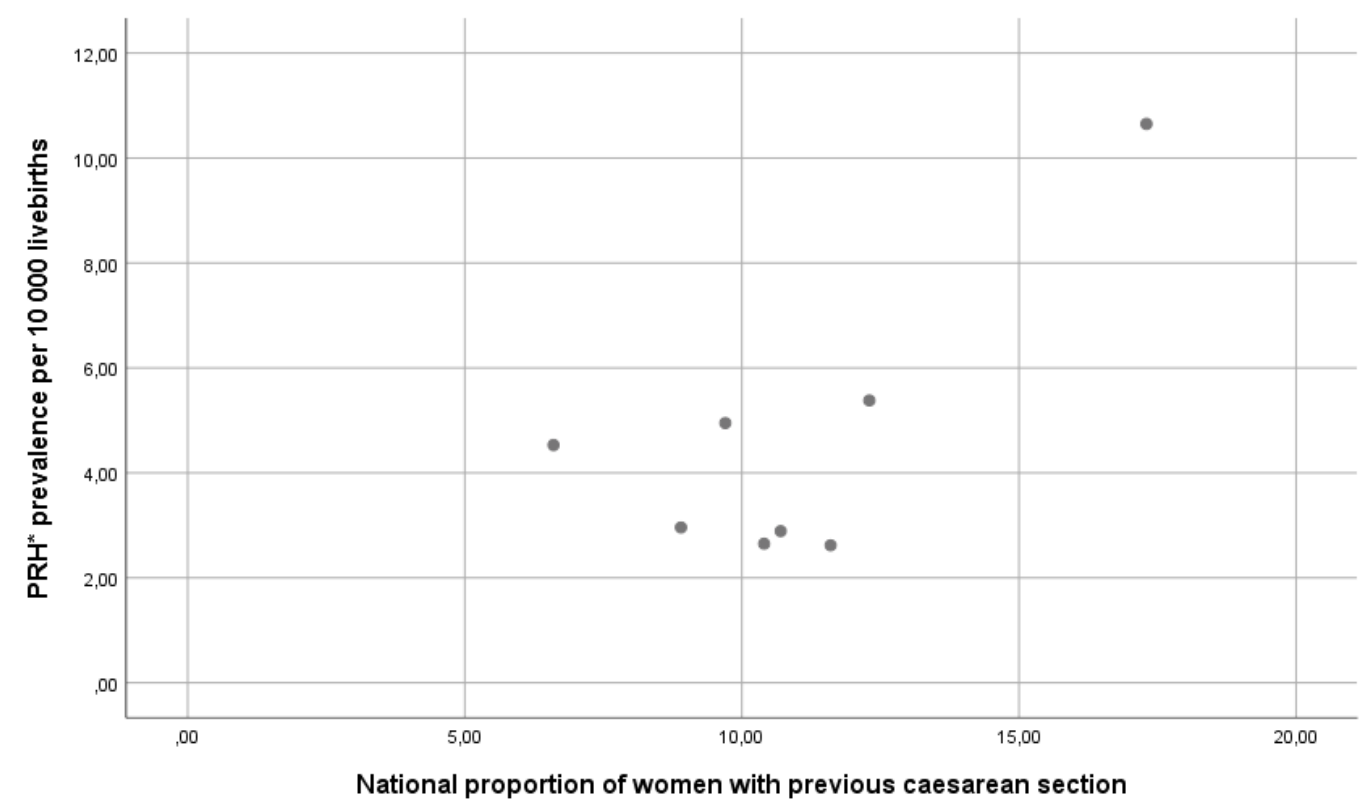

aogs_13892_f3.tif 